\title{
Road safety research in a safety audit
}

\author{
Rumiya Mukhametshina*[0000-0002-1215-263x] , and Ramil Zagidullin ${ }^{1}$ \\ ${ }^{1}$ Kazan State University of Architecture and Engineering, 420043 Kazan, Russia
}

\begin{abstract}
The article reviews the option of how to make the top pavement of asphalt-concrete mixture adhere reliably to the base, which is the underlying cement-concrete coating. The bitumen-latex emulsion is suggested as a binder for the two pavement layers.
\end{abstract}

Keywords. Road safety, audit methodology, highways, road traffic accidents, X-shaped intersection, crossroads, hazardous areas.

\section{Introduction}

The motor vehicle fleet grows steadily country-wide, as does their carrying capacity, cargo sizes, and traffic intensity and speed. As a result, there is a greater demand for betterfunctioning roads [1-3].

The World Health Organization also notes that without urgent measures, road traffic injuries will become the fifth cause of death by 2030 . Based on this, it can be argued that the issue of organizing a road safety audit is currently relevant, which is already being applied in many European countries and the United States. The implementation of such measures, according to international statistics, affects the reduction of the level of accidents in settlements and on highways $[4,5]$.

In Russia, the number of cars, primarily passenger cars, is growing every year. As you know, the level of accidents directly depends on the level of motorization of the country. The number of cars is growing, the number of accidents is growing. Nevertheless, there is a feeling that in the Russian Federation the main part of accidents occurs for some other reasons than in other countries. The number of vehicles in our country is about 300 cars per thousand people, which is about two times lower than in Western Europe, the United States, Canada, and Japan [6-8]. Even in the countries of Eastern Europe, the number of cars is one and a half times higher than in our country [9].

The increasing increase in traffic intensity on the roads contributes to the increased relevance of traffic safety issues for traffic management services [10-12]. Currently, road traffic, in which the three main components interact-a person, a car, a road-is becoming an increasingly complex process due to the following factors:

1. Expansion of the road network.

2. Growth in the rate of motorization.

3. Heterogeneity of the composition of transport flows.

4. The appearance on the roads of a large number of drivers without experience in driving a vehicle.

*Corresponding author: rumya211@yandex.ru 
5. Financial restrictions in the construction, maintenance and repair of highways.

In some countries, the «Safety Audit» method is used to monitor road safety. Countries such as the United Kingdom, New Zealand, Australia, the United States, Canada, South Africa, Denmark, the Netherlands, Singapore use the existing method of «Safety Audit» on their roads for almost two decades, because of its high performance [13-15]. It can be argued that the Nordic countries also use the methods of road safety audit, although the term «Safety Audit» is not used, but the elements of the concept of road safety audit are contained in the procedures for the development of a road project at three stages: the design stage, the construction stage and the operation stage. In a number of countries, such as the United Kingdom, Sweden, Finland, and the Netherlands, there is a steady decline in road accidents. In addition, their roads are considered the safest, according to international statistics, due to the widespread use of road safety audit practices.

In the world practice, in order to improve the safety and comfort of road traffic, actively used the audit methodology $[16,17]$. Thanks to this approach, it is possible to perform an objective and independent assessment of road conditions and develop measures to eliminate shortcomings, which allows you to reduce the level of accidents on highways by $20-30 \%$.

Performing audit tasks is as follows:

1. Identification of the most dangerous areas.

2. Ranking of sites according to the degree of danger for the subsequent priority survey and analysis of the causes of accidents.

3. Determining the most effective allocation of road safety resources when planning activities.

4. Follow-up monitoring of dangerous road sections.

Identifying and ranking the most dangerous road sections is a particularly important stage of the audit, in terms of further in-depth analysis of the potential causes of accidents and taking measures to improve road safety.

The purpose of the study is to apply a safety audit and eliminate possible causes of road accidents in advance during road operation.

\section{Materials and methods}

This article uses references to the following standards:

1. GOST R 50597-93 Highways and streets. Requirements for the operational state permissible under the conditions of ensuring road safety.

2. GOST R 52289-2004 Technical means of traffic management. Rules for the use of road signs, markings, traffic lights, road barriers and guiding devices.

3. GOST R 52766-2007 Motor roads for general use. Arrangement elements. General requirements.

4. SP 34.13330.2012 Highways (updated edition of SNiP 2.05.02-85).

5. SP 52.13330.2011 Set of rules. Natural and artificial lighting (updated edition of SNiP 23-05-95*).

6. ODM 218.6.027-2017 «Rekomendacii po provedeniyu audita bezopasnosti dorozhnogo dvizheniya pri proektirovanii, stroitel'stve i ekspluatacii avtomobil'nyh dorog».

When analyzing the methods for determining the accident rate, in order to identify the necessary method for predicting an accident for the road safety audit at the road design stage, the method for determining the final accident rate of prof. Babkov V.F. [1].

One of the priority problems facing the Republic of Tatarstan is the high level of accidents, as a result of which the republic suffers great socio-economic losses. The reason for the high level of accidents is the rapid growth in the level of motorization of the population of the republic, which entails such consequences as:

- massive inclusion of new drivers and carriers in road traffic; 
- changing the characteristics and conditions of road traffic;

- increase in traffic density;

- increasing the intensity on highways and streets in cities and towns;

- decrease in the mobility of the population.

Changing the road network of the Republic of Tatarstan is possible in two ways: extensive and intensive.

The extensive method involves the further expansion and repair of existing roads, the construction of new ones, an increase in traffic density, etc. This method provides significant financial resources for the construction of new roads and for the subsequent operation and maintenance of highways [18].

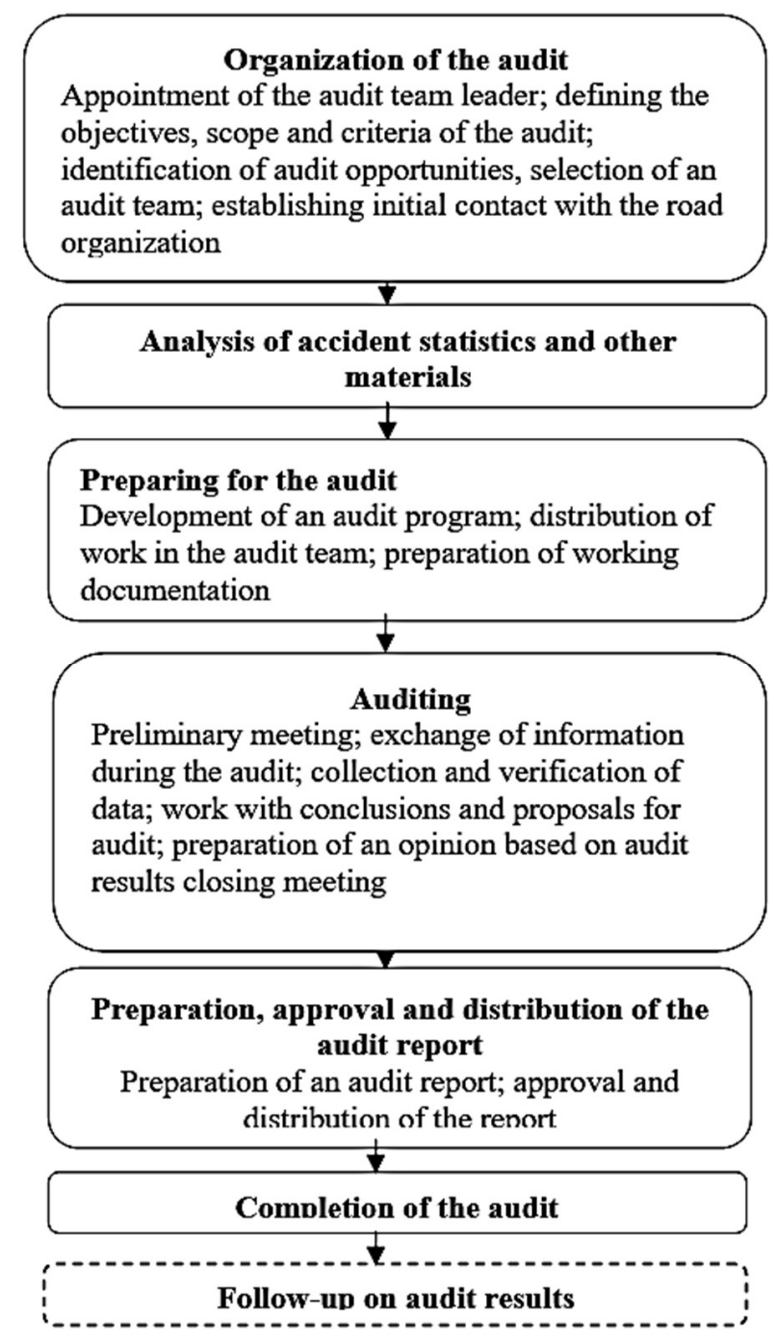

Fig. 1. Typical audit trail (dotted lines indicate that audit follow-up is not part of the audit).

The intensive method is to improve the performance of the existing road network by improving its performance. This method requires rational management of existing roads, which helps to increase the capacity of bottlenecks, improve the smoothness of traffic flows in order to increase the productivity of the entire road network [19]. 
The main way to reduce the accident rate is the intensive method, since the road network of the Republic of Tatarstan has been formed to date, but at the same time it requires improving the performance of highways. The structure of the system has a decisive influence on the entire set of its properties. Therefore, while improving numerous subsystems in the field of road safety management, the main problem is the creation of the organizational structure of regional road safety management systems in the Republic of Tatarstan.

A typical audit scheme is shown in fig. 1. The depth and scope of an audit will depend on the scope and complexity of the particular audit.

Based on the description of the stages and objectives of the audit, the development of methodological recommendations for conducting a step-by-step safety assessment is a necessary procedure. It is mandatory to form control sheets by auditors for the subsequent analysis of accident rates, as well as for making decisions to increase the safety of dangerous areas and eliminate defects on the road. To determine the accident rates at various stages of the BDD audit, we propose to apply the methods according to the developed classification [20], which includes 5 groups of methods. The first group includes methods based on the processing of statistical data on road accidents. The second category includes methods based on determining the parameters of traffic conditions. The third category includes methods based on the analysis of conflict situations [21]. Fourth - methods based on the assessment of the driver's behavior [22]. The fifth group consists of methods based on an integrated approach to the assessment of BDD-the qualimetric method [23] and the accident rate analysis taking into account the macroscopic indicators of the region.

Fig. 2 shows the most emergency locations on the P-239 road (Kazan - Orenburg) on the territory of the Republic of Tatarstan.

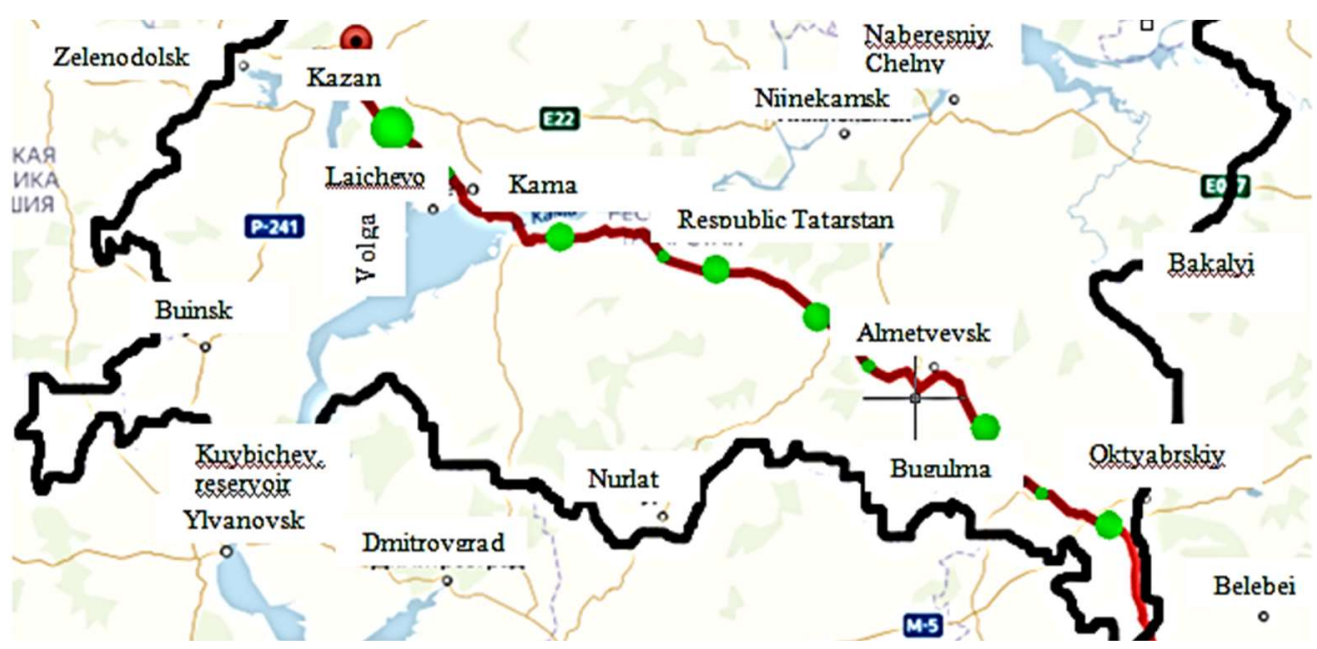

Fig. 2. The most emergency places on the P-239 road (Kazan - Orenburg) on the territory of the Republic of Tatarstan.

Road P-239 (Kazan - Orenburg - Akbulak - border with the Republic of Kazakhstan) is a federal highway with an asphalt covering about $900 \mathrm{~km}$ long, connecting the cities of Kazan, Chistopol, Almetyevsk, Bugulma, Bavly, Orenburg, Sol-Iletsk, Akbulak.

The main Orenburg tract of the city of Kazan is the beginning of the motor road of the P-239 highway. Also, the Orenburg tract is the main road to the international airport «Kazan», therefore the tract is designed as a full-fledged four-lane highway with divided carriageways and lighting in the dark until the junction with the road to the airport (P-245).

On the territory of Laishevsky district, the tract narrows to a two-lane road without lighting at night, and passes by such settlements as the village of Sokury, the village of 
Imenkovo, the village of Polyanka, where the permitted speed limit is limited to $40 \mathrm{~km} / \mathrm{h}$, and then the tract passes into a bridge across the Kama River.

The main transport artery on the territory of the Alekseevsky district also remains the P239 highway, where the speed limit remains $40 \mathrm{~km} / \mathrm{h}$ throughout the Alekseevsky settlement. The section of the Alekseevskoye-Sakharovka road is laid from west to east and there are practically no turns on it, which allows overtaking long or slow-moving vehicles.

The city of Chistopol is located on the next path and this road bypasses it from the south, forming the «Chistopol bypass road». At the end of the bypass road at an X-shaped intersection, the road rushes to the southeast, where there are a significant number of descents and ascents, which contributes to the prohibition of overtaking and speed limits.

Crossing the Novosheshmiskiy district, or rather its northeastern part diagonally, the road has significant bends and also runs through the hills.

Approaching the Almetyevsk district, the road crosses a regulated railway crossing (the Akbash-Agryz line), after which, at the T-junction, you can turn right towards the city of Leninogorsk. After that, the road partially runs through the city of Almetyevsk. Further, the road goes along the Lower Maktama, where the movement of motor transport to the village of Abdrakhmanovo is significantly hampered, in which the speed limit is limited to $40 \mathrm{~km} / \mathrm{h}$.

To the X-shaped intersection in front of the town of Bugulma, the road runs past the village of Karabash. At the crossroads, the road turns right, bypassing the city, but it is also possible to drive through Bugulma, where the speed limit is limited to $50 \mathrm{~km} / \mathrm{h}$.

Approaching the Bavlinsky district, the road passes three villages (Vostochny, Staroye and Novoye Isakovo). Before the Bavlisky crossroads, you need to overcome a protracted ascent of more than $1400 \mathrm{~m}$, and already at the crossroads a roundabout is organized, where the P-239 is secondary to the M5 Ural.

After the crossroads, the P-239 road passes through the town of Bavly, where traffic is limited to $40 \mathrm{~km} / \mathrm{h}$, and in some places, there are signs «No overtaking». Passing through the village of Shalty, where the speed limit is also limited to $40 \mathrm{~km} / \mathrm{h}$, the road reaches the border of the Republic of Tatarstan and the Orenburg region. A stele was erected to commemorate this.

\section{Results}

Accident rates show that in recent years on the P-239 road in the territory of the Republic of Tatarstan, there has been a decrease in the number of deaths and injuries, fig. 3 and Table 1.

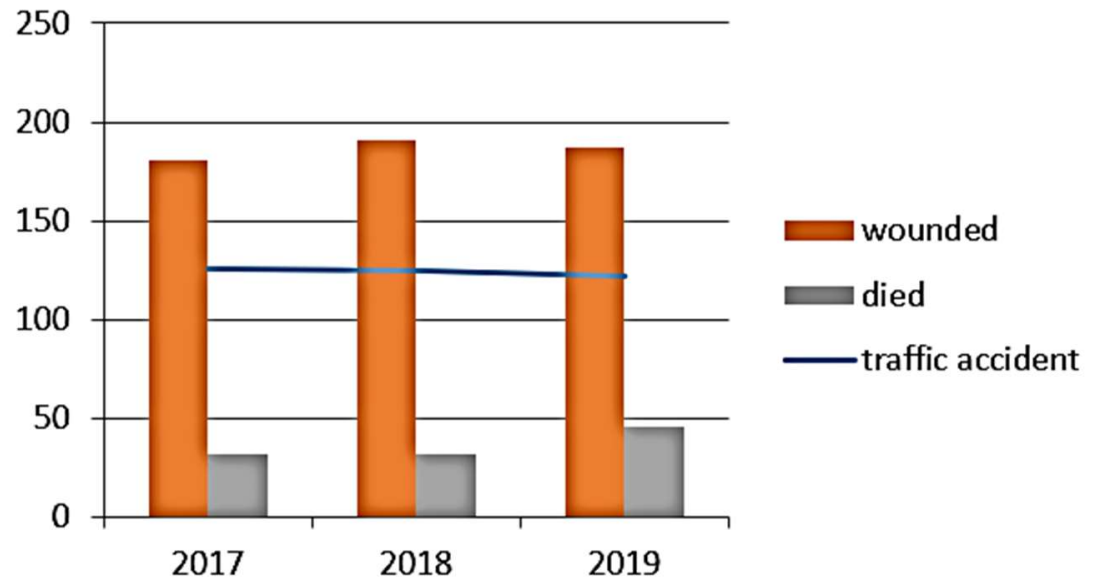

Fig. 3. Dynamics of accidents on the P-239 road for 2017-2019. 
Table 1. Dynamics of accidents on the P-239 road for 2017-2019.

\begin{tabular}{|c|c|c|c|}
\hline Years & Road accident & Wounded & Perished \\
\hline 2017 & 126 & 181 & 32 \\
\hline 2018 & 125 & 191 & 32 \\
\hline 2019 & 122 & 187 & 46 \\
\hline
\end{tabular}

The dynamics of road accidents is shown in fig. 4.

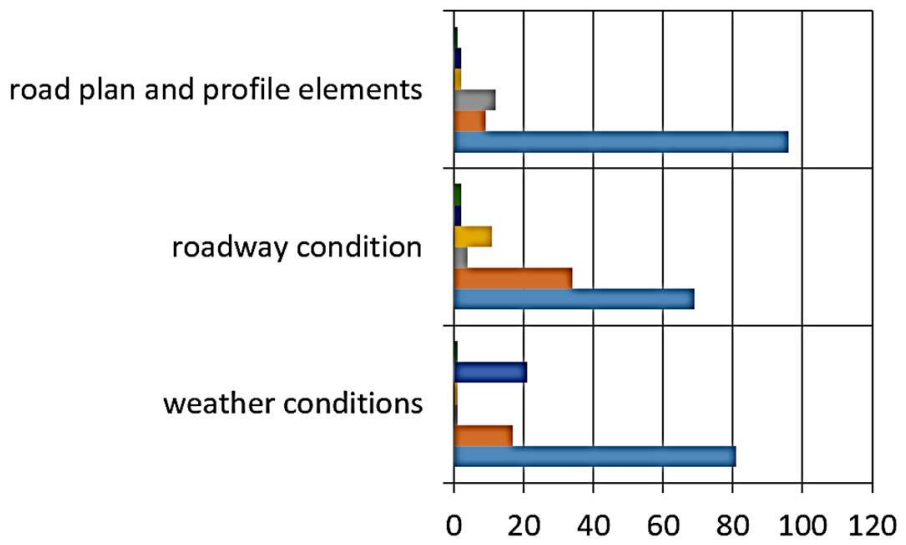

Fig. 4. Dynamics of road accidents on the R-239 road.

In accordance with the currently valid Rules for accounting and analysis of road accidents on highways, hazardous areas are determined mainly based on the values of the relative accident rate or the risk of road accidents (the number of accidents per 1 million vehicle-km), calculated by the formula:

where:

$$
Z=\frac{n \cdot 10^{6}}{N \cdot L \cdot m \cdot 365}
$$

$n$ is the number of accidents on the road section for the billing period;

$N$ is the average annual daily traffic intensity, bus/day;

$L$ is the length of the section under consideration, $\mathrm{km}$;

$M$ is the number of years in the billing period.

The peculiarity of this indicator is that it characterizes the frequency of dangerous events - registration accidents (with victims), but does not take into account the severity of their consequences. However, in practice, cases with a large number of dead and injured road users are always socially significant events. In such incidents, investigations are carried out with the participation of road and other organizations and services. Another difference also consists in the fact that, as a rule, measures for passive road safety are implemented in such sections. The essence of increasing passive safety on highways is to reduce the severity of the consequences of road accidents by extinguishing the kinetic energy of the vehicle or changing the trajectory of the vehicle. That is why, along with assessing the hazard of road sections in terms of the risk of road accidents, it is necessary to assess them according to the severity of the consequences of accidents.

These indicators are not opposed to each other, but make it possible to more objectively (comprehensively) assess the degree of danger of road sections. These indicators are characterized by different quantitative scales, therefore, one of the methods of presenting them as a complex indicator is the rating approach in the form of average values of the places of hazard ranks of the sites. 
Studies on the application of the hazard rating indicator for road sections were carried out on the section of the federal road R-239 Kazan - Orenburg (11 km by $399 \mathrm{~km})$. Statistical analysis of road accidents on a $388 \mathrm{~km}$ section showed that during 2017-2019 the total number of road accidents was 373, the number of deaths and injuries in them was 110 and 559 people, respectively.

The severity of the consequences of an accident $(\mathrm{T})$ on the road section was estimated using the following formula:

where:

$$
T=\frac{D \cdot L}{D+W} \cdot 100
$$

$D$ is the number of fatalities in road accidents per year;

$W$ is the number of injured per year;

$L$ is the length of the section under consideration, $\mathrm{km}$.

The risk assessment of road accidents on the road sections was carried out according to the formula (1). Based on the place in the list, the sites were assigned values of ranks $r 1$ and r2 from 1 to 389 (table 2).

Table 2. Assessment of the hazard of sections of the P-239 road depending on the values of the risk indicators and the severity of road accidents.

\begin{tabular}{|c|c|c|c|c|c|c|c|c|}
\hline № & $\begin{array}{c}\text { Km } \\
\text { of } \\
\text { road }\end{array}$ & $\begin{array}{l}\text { Number } \\
\text { of road } \\
\text { accidents }\end{array}$ & $\begin{array}{c}\text { Number } \\
\text { of } \\
\text { victims }\end{array}$ & $\begin{array}{l}\text { Number } \\
\text { of } \\
\text { injured }\end{array}$ & $\begin{array}{c}\text { Severity of } \\
\text { the } \\
\text { consequences } \\
\text { of a road } \\
\text { accident }\end{array}$ & $\begin{array}{c}\text { Rank, } \\
r_{1}\end{array}$ & $\begin{array}{c}\text { Assessment } \\
\text { of the risk of } \\
\text { a road } \\
\text { accident }\end{array}$ & $\begin{array}{c}\text { Rank, } \\
r_{2}\end{array}$ \\
\hline 1 & 11 & 3 & 0 & 3 & 0 & 84 & 0.096452 & 37 \\
\hline 2 & 12 & 3 & 0 & 3 & 0 & 83 & 0.096452 & 36 \\
\hline 3 & 13 & 4 & 0 & 6 & 0 & 72 & 0.128603 & 16 \\
\hline 4 & 14 & 4 & 0 & 8 & 0 & 71 & 0.128603 & 15 \\
\hline 5 & 15 & 2 & 0 & 5 & 0 & 119 & 0.064301 & 93 \\
\hline 6 & 16 & 1 & 0 & 1 & 0 & 213 & 0.032151 & 213 \\
\hline 7 & 17 & 0 & 0 & 0 & 0 & 389 & 0 & 389 \\
\hline 8 & 18 & 1 & 0 & 1 & 0 & 212 & 0.032151 & 212 \\
\hline 9 & 19 & 0 & 0 & 0 & 0 & 388 & 0 & 388 \\
\hline 10 & 20 & 1 & 0 & 1 & 0 & 211 & 0.032151 & 211 \\
\hline 11 & 21 & 2 & 0 & 3 & 0 & 118 & 0.064301 & 92 \\
\hline 12 & 22 & 3 & 0 & 7 & 0 & 82 & 0.096452 & 35 \\
\hline 13 & 23 & 6 & 1 & 7 & 12.5 & 63 & 0.192904 & 2 \\
\hline 14 & 24 & 3 & 1 & 4 & 20 & 55 & 0.096452 & 34 \\
\hline 15 & 25 & 5 & 1 & 4 & 20 & 53 & 0.160754 & 7 \\
\hline 16 & 26 & 2 & 2 & 2 & 50 & 21 & 0.064301 & 91 \\
\hline 17 & 27 & 4 & 0 & 3 & 0 & 70 & 0.128603 & 14 \\
\hline 18 & 28 & 5 & 0 & 5 & 0 & 65 & 0.160754 & 6 \\
\hline 19 & 29 & 0 & 0 & 0 & 0 & 387 & 0 & 387 \\
\hline 20 & 30 & 3 & 0 & 5 & 0 & 81 & 0.096452 & 33 \\
\hline 21 & 31 & 1 & 1 & 0 & 100 & 1 & 0.032151 & 210 \\
\hline 22 & 32 & 4 & 3 & 7 & 30 & 43 & 0.128603 & 13 \\
\hline 23 & 33 & 2 & 1 & 3 & 25 & 47 & 0.064301 & 90 \\
\hline 24 & 34 & 1 & 1 & 0 & 100 & 2 & 0.032151 & 209 \\
\hline 25 & 35 & 1 & 0 & 2 & 0 & 210 & 0.032151 & 208 \\
\hline 26 & 36 & 3 & 2 & 9 & 18.18182 & 60 & 0.096452 & 32 \\
\hline 27 & 37 & 0 & 0 & 0 & 0 & 386 & 0 & 386 \\
\hline 28 & 38 & 1 & 0 & 1 & 0 & 209 & 0.032151 & 207 \\
\hline 29 & 39 & 1 & 0 & 1 & 0 & 208 & 0.032151 & 206 \\
\hline 30 & 40 & 1 & 1 & 0 & 100 & 3 & 0.032151 & 205 \\
\hline 31 & 41 & 1 & 0 & 1 & 0 & 207 & 0.032151 & 204 \\
\hline 32 & 42 & 1 & 0 & 1 & 0 & 206 & 0.032151 & 203 \\
\hline 33 & 43 & 0 & 0 & 0 & 0 & 385 & 0 & 385 \\
\hline 34 & 44 & 1 & 0 & 2 & 0 & 205 & 0.032151 & 202 \\
\hline
\end{tabular}




\begin{tabular}{|c|c|c|c|c|c|c|c|c|}
\hline 35 & 45 & 0 & 0 & 0 & 0 & 384 & 0 & 384 \\
\hline 36 & 46 & 4 & 5 & 10 & 33.33333 & 34 & 0.128603 & 12 \\
\hline 37 & 47 & 2 & 2 & 0 & 100 & 13 & 0.064301 & 89 \\
\hline 38 & 48 & 0 & 0 & 0 & 0 & 383 & 0 & 383 \\
\hline 39 & 49 & 1 & 0 & 1 & 0 & 204 & 0.032151 & 201 \\
\hline 40 & 50 & 0 & 0 & 0 & 0 & 382 & 0 & 382 \\
\hline 41 & 51 & 0 & 0 & 0 & 0 & 381 & 0 & 381 \\
\hline 42 & 52 & 0 & 0 & 0 & 0 & 380 & 0 & 380 \\
\hline 43 & 53 & 3 & 2 & 6 & 25 & 51 & 0.096452 & 31 \\
\hline 44 & 54 & 0 & 0 & 0 & 0 & 379 & 0 & 379 \\
\hline 45 & 55 & 1 & 0 & 1 & 0 & 203 & 0.032151 & 200 \\
\hline 46 & 56 & 1 & 0 & 1 & 0 & 202 & 0.032151 & 199 \\
\hline 47 & 57 & 1 & 3 & 1 & 75 & 14 & 0.032151 & 198 \\
\hline 48 & 58 & 0 & 0 & 0 & 0 & 378 & 0 & 378 \\
\hline 49 & 59 & 1 & 0 & 1 & 0 & 201 & 0.032151 & 197 \\
\hline 50 & 60 & 1 & 1 & 0 & 100 & 4 & 0.032151 & 196 \\
\hline 51 & 61 & 0 & 0 & 0 & 0 & 377 & 0 & 377 \\
\hline 52 & 62 & 1 & 0 & 1 & 0 & 200 & 0.032151 & 195 \\
\hline 53 & 63 & 0 & 0 & 0 & 0 & 376 & 0 & 376 \\
\hline 54 & 64 & 2 & 1 & 2 & 33.33333 & 38 & 0.064301 & 88 \\
\hline 55 & 65 & 1 & 0 & 3 & 0 & 199 & 0.032151 & 194 \\
\hline 56 & 66 & 1 & 1 & 0 & 100 & 5 & 0.032151 & 193 \\
\hline 57 & 67 & 4 & 0 & 5 & 0 & 69 & 0.128603 & 11 \\
\hline 58 & 68 & 3 & 4 & 6 & 40 & 32 & 0.096452 & 30 \\
\hline 59 & 69 & 0 & 0 & 0 & 0 & 375 & 0 & 375 \\
\hline 60 & 70 & 0 & 0 & 0 & 0 & 374 & 0 & 374 \\
\hline 61 & 71 & 3 & 1 & 6 & 14.28571 & 62 & 0.096452 & 29 \\
\hline 62 & 72 & 1 & 0 & 1 & 0 & 198 & 0.032151 & 192 \\
\hline 63 & 73 & 0 & 0 & 0 & 0 & 373 & 0 & 373 \\
\hline 64 & 74 & 1 & 0 & 1 & 0 & 197 & 0.032151 & 191 \\
\hline 65 & 75 & 0 & 0 & 0 & 0 & 372 & 0 & 372 \\
\hline 66 & 76 & 0 & 0 & 0 & 0 & 371 & 0 & 371 \\
\hline 67 & 77 & 0 & 0 & 0 & 0 & 370 & 0 & 370 \\
\hline 68 & 78 & 0 & 0 & 0 & 0 & 369 & 0 & 369 \\
\hline 69 & 79 & 0 & 0 & 0 & 0 & 368 & 0 & 368 \\
\hline 70 & 80 & 0 & 0 & 0 & 0 & 367 & 0 & 367 \\
\hline 71 & 81 & 0 & 0 & 0 & 0 & 366 & 0 & 366 \\
\hline 72 & 82 & 0 & 0 & 0 & 0 & 365 & 0 & 365 \\
\hline 73 & 83 & 0 & 0 & 0 & 0 & 364 & 0 & 364 \\
\hline 74 & 84 & 0 & 0 & 0 & 0 & 363 & 0 & 363 \\
\hline 75 & 85 & 1 & 0 & 2 & 0 & 196 & 0.032151 & 190 \\
\hline 76 & 86 & 2 & 1 & 4 & 20 & 59 & 0.064301 & 87 \\
\hline 77 & 87 & 0 & 0 & 0 & 0 & 362 & 0 & 362 \\
\hline 78 & 88 & 1 & 1 & 1 & 50 & 17 & 0.032151 & 189 \\
\hline 79 & 89 & 0 & 0 & 0 & 0 & 361 & 0 & 361 \\
\hline 80 & 90 & 0 & 0 & 0 & 0 & 360 & 0 & 360 \\
\hline 81 & 91 & 6 & 1 & 6 & 14.28571 & 62 & 0.192904 & 1 \\
\hline 82 & 92 & 2 & 0 & 6 & 0 & 117 & 0.064301 & 86 \\
\hline 83 & 93 & 1 & 2 & 1 & 66.66667 & 15 & 0.032151 & 188 \\
\hline 84 & 94 & 1 & 0 & 1 & 0 & 195 & 0.032151 & 187 \\
\hline 85 & 95 & 1 & 4 & 0 & 100 & 6 & 0.032151 & 186 \\
\hline 86 & 96 & 5 & 1 & 4 & 20 & 52 & 0.160754 & 5 \\
\hline 87 & 97 & 1 & 0 & 1 & 0 & 194 & 0.032151 & 185 \\
\hline 88 & 98 & 2 & 0 & 7 & 0 & 116 & 0.064301 & 85 \\
\hline 89 & 99 & 2 & 0 & 3 & 0 & 115 & 0.064301 & 84 \\
\hline 90 & 100 & 0 & 0 & 0 & 0 & 359 & 0 & 359 \\
\hline 91 & 101 & 2 & 1 & 1 & 50 & 22 & 0.064301 & 83 \\
\hline 92 & 102 & 2 & 0 & 4 & 0 & 114 & 0.064301 & 82 \\
\hline 93 & 103 & 2 & 0 & 4 & 0 & 113 & 0.064301 & 81 \\
\hline 94 & 104 & 1 & 0 & 1 & 0 & 193 & 0.032151 & 184 \\
\hline 95 & 105 & 1 & 0 & 2 & 0 & 192 & 0.032151 & 183 \\
\hline
\end{tabular}




\begin{tabular}{|c|c|c|c|c|c|c|c|c|}
\hline 96 & 106 & 0 & 0 & 0 & 0 & 358 & 0 & 358 \\
\hline 97 & 107 & 0 & 0 & 0 & 0 & 357 & 0 & 357 \\
\hline 98 & 108 & 2 & 0 & 4 & 0 & 112 & 0.064301 & 80 \\
\hline 99 & 109 & 2 & 0 & 7 & 0 & 111 & 0.064301 & 79 \\
\hline 100 & 110 & 1 & 0 & 1 & 0 & 191 & 0.032151 & 182 \\
\hline 101 & 111 & 0 & 0 & 0 & 0 & 356 & 0 & 356 \\
\hline 102 & 112 & 2 & 1 & 2 & 33.33333 & 37 & 0.064301 & 78 \\
\hline
\end{tabular}

After the procedure for assessing the hazard of sections of the P-239 road, depending on the values of the risk indicators and the severity of an accident in the range from 1 to 389, the road sections are ranked according to the degree of danger.

Table 3. Ranking of road sections according to the degree of danger.

\begin{tabular}{|c|c|c|c|c|c|c|c|c|c|c|c|c|c|c|}
\hline № & 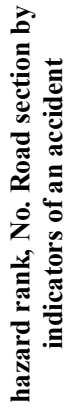 & 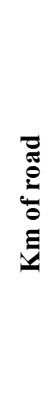 & 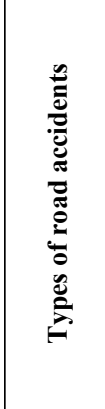 & 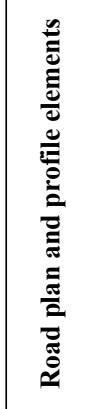 & 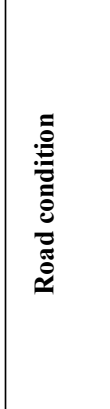 & 烂 & 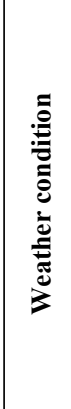 & 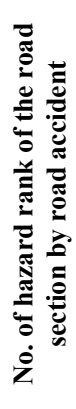 & 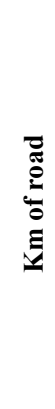 & 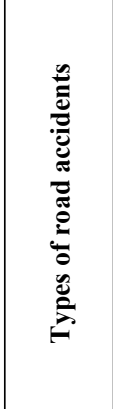 & 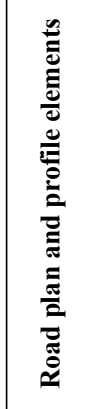 & 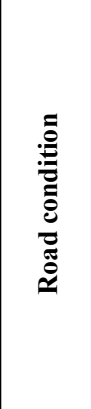 & $\stackrel{000}{.00}$ & 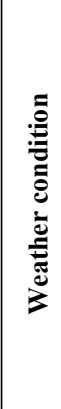 \\
\hline 1 & 1 & 31 & collision & $\begin{array}{l}\text { straight } \\
\text { in plan, }\end{array}$ & dry & day & clear & 1 & 91 & $\begin{array}{c}\text { collision, } \\
\text { other type } \\
\text { of road } \\
\text { accident }\end{array}$ & $\begin{array}{l}\begin{array}{l}\text { straight } \\
\text { in plan }\end{array} \\
\end{array}$ & dry & included & clear \\
\hline 2 & 2 & 34 & $\begin{array}{c}\text { other type } \\
\text { of road } \\
\text { accident }\end{array}$ & $\begin{array}{l}\text { straight } \\
\text { in plan, }\end{array}$ & dry & $\begin{array}{c}\text { not } \\
\text { included }\end{array}$ & clear & 2 & 23 & collision & \begin{tabular}{|l} 
straight \\
in plan
\end{tabular} & process & day & $\begin{array}{l}\text { over- } \\
\text { cast, } \\
\text { rain }\end{array}$ \\
\hline 3 & 3 & 40 & $\begin{array}{c}\text { hitting an } \\
\text { obstacle }\end{array}$ & $\begin{array}{l}\text { straight } \\
\text { in plan }\end{array}$ & dry & day & clear & 3 & 302 & collision & $\begin{array}{c}\text { straight } \\
\text { in plan, } \\
\text { slope }\end{array}$ & process & day & snow \\
\hline 4 & 4 & 60 & collision & $\begin{array}{l}\text { straight } \\
\text { in plan, }\end{array}$ & processed & day & snowf & 4 & 114 & collision & $\begin{array}{l}\text { straight } \\
\text { in plan }\end{array}$ & wet & day & $\begin{array}{l}\text { over- } \\
\text { cast, } \\
\text { rain }\end{array}$ \\
\hline 5 & 5 & 66 & $\begin{array}{c}\text { other type } \\
\text { of road } \\
\text { accident }\end{array}$ & $\begin{array}{l}\text { straight } \\
\text { in plan }\end{array}$ & dry & $\begin{array}{c}\text { not } \\
\text { included }\end{array}$ & clear & 5 & 96 & collision & $\begin{array}{l}\text { straight } \\
\text { in plan }\end{array}$ & $\begin{array}{l}\text { snowy, } \\
\text { ice }\end{array}$ & included & $\begin{array}{l}\text { over- } \\
\text { cast, } \\
\text { snow }\end{array}$ \\
\hline 6 & 6 & 95 & collision & $\begin{array}{l}\text { straight } \\
\text { in plan }\end{array}$ & processed & $\begin{array}{c}\text { not } \\
\text { included }\end{array}$ & snow & 6 & 28 & $\begin{array}{c}\text { collision, } \\
\text { over- } \\
\text { turning }\end{array}$ & $\begin{array}{l}\text { straight } \\
\text { in plan }\end{array}$ & dry & $\begin{array}{c}\text { not } \\
\text { included }\end{array}$ & clear \\
\hline 7 & 7 & 124 & collision & $\begin{array}{l}\text { straight } \\
\text { in plan }\end{array}$ & processed & day & snow & 7 & 25 & $\begin{array}{c}\text { collision } \\
\text { with a } \\
\text { stationary } \\
\text { vehicle }\end{array}$ & $\begin{array}{l}\text { straight } \\
\text { in plan }\end{array}$ & dry & day & clear \\
\hline 8 & 8 & 165 & $\begin{array}{c}\text { other type } \\
\text { of road } \\
\text { accident }\end{array}$ & $\begin{array}{l}\text { straight } \\
\text { in plan }\end{array}$ & dry & day & clear & 8 & 313 & $\begin{array}{c}\text { collision, } \\
\text { over- } \\
\text { turning }\end{array}$ & $\begin{array}{l}\text { straight } \\
\text { in plan }\end{array}$ & dry & day & clear \\
\hline 9 & 9 & 177 & $\begin{array}{l}\text { collision, } \\
\text { other type } \\
\text { of road } \\
\text { accident }\end{array}$ & $\begin{array}{c}\text { straight } \\
\text { in plan, } \\
\text { slope }\end{array}$ & processed & day & snow & 9 & 238 & $\begin{array}{c}\text { over- } \\
\text { turning }\end{array}$ & $\begin{array}{l}\text { straight } \\
\text { in plan, } \\
\text { slope }\end{array}$ & wet & day & rain \\
\hline 10 & 10 & 230 & $\begin{array}{l}\text { other type } \\
\text { of road } \\
\text { accident }\end{array}$ & $\begin{array}{l}\text { straight } \\
\text { in plan, } \\
\text { slope }\end{array}$ & dry & day & clear & 10 & 113 & $\begin{array}{c}\text { collision, } \\
\text { over- } \\
\text { turning }\end{array}$ & $\begin{array}{c}\text { straight } \\
\text { in plan, } \\
\text { slope }\end{array}$ & dry & day & clear \\
\hline
\end{tabular}

As can be seen from table 3, the most dangerous sections of the road in terms of the severity of the accident consequences include $31 \mathrm{~km}, 34 \mathrm{~km}, 40 \mathrm{~km}, 60 \mathrm{~km}, 66 \mathrm{~km}, 95 \mathrm{~km}$, $124 \mathrm{~km}, 165 \mathrm{~km}, 177 \mathrm{~km}$ and $230 \mathrm{~km}$, and the risk indicator of an accident should include 91 $\mathrm{km}, 23 \mathrm{~km}, 302 \mathrm{~km}, 114 \mathrm{~km}, 96 \mathrm{~km}, 28 \mathrm{~km}, 25 \mathrm{~km}, 313 \mathrm{~km}, 238 \mathrm{~km}, 113 \mathrm{~km}$. The data show 
that if the 10 most dangerous sections of the road are assessed in terms of severity of consequences and the risk of road accidents, then there is no coincidence for all sections.

\section{Discussion}

The person in the management system is the most important and at the same time less reliable link. He is easily distracted, gets tired relatively quickly, his behavior is influenced by a lot of unpredictable factors, and therefore he can not accurately perform the work for a long time. The failure rate in control systems due to human fault ranges from 20 to $95 \%$.

Such failures in the VADS control system pose a major threat to road safety. Roads and traffic management are often taken for granted and focus one-sidedly on how the road user adapts to the system. The contribution of the human factor to the occurrence of an accident is the more significant, the more technically perfect the road is. For example, on motorways, many possible errors are eliminated. Motorways have no level crossings, no unexpected turns, no pedestrian and bicycle paths, etc. However, therefore, the accidents that occur on such roads are largely attributed to the human factor $[24,25]$.

The main measures for road safety in Kazan, for various types of road safety problems, can be divided into:

1. Measures against various types of accidents.

2. Measures against risk factors in road traffic.

3. Measures aimed at groups of road users with a high risk of injury.

It should be noted that, unlike many European countries, in Russia, the audit of pedestrian crossings is often not used and not developed the scientific and methodological foundations. In this regard, methods for determining the size and location of pedestrian crossings, as well as the size of safety islands and the height of curbs, depending on the parameters of traffic and pedestrian flows and the width of the roadway, were identified and refined to practical application [26, 27]. To obtain practical results of the BDD audit, control sheets are used for the audit at various stages and places of their implementation, in order to form recommendations for eliminating technical errors and correct perception of traffic conditions by the participants of the BDD.

\section{Conclusions}

1. Road P-239 (Kazan-Orenburg - Akbulak - border with the Republic of Kazakhstan) - a federal highway with an asphalt surface, about $900 \mathrm{~km}$ long, connecting the cities of Kazan, Chistopol, Almetyevsk, Bugulma, Bavly, Orenburg, Sol-Iletsk, Akbulak.

2. Studies on the application of the hazard rating indicator for road sections were carried out on the section of the federal road P-239 Kazan - Orenburg (11 km by $399 \mathrm{~km})$. Statistical analysis of road accidents on a section with a length of $388 \mathrm{~km}$ showed that during 20172019. the total number of road accidents was 373 , the number of deaths and injuries in them - respectively 110 and 559 people.

3. The most dangerous sections of the road in terms of the severity of the consequences of road accidents include $31 \mathrm{~km}, 34 \mathrm{~km}, 40 \mathrm{~km}, 60 \mathrm{~km}, 66 \mathrm{~km}, 95 \mathrm{~km}, 124 \mathrm{~km}, 165 \mathrm{~km}, 177$ $\mathrm{km}$ and $230 \mathrm{~km}$. According to the accident risk indicator, $91 \mathrm{~km}, 23 \mathrm{~km}, 302 \mathrm{~km}, 114 \mathrm{~km}, 96$ $\mathrm{km}, 28 \mathrm{~km}, 25 \mathrm{~km}, 313 \mathrm{~km}, 238 \mathrm{~km}, 113 \mathrm{~km}$ should be attributed.

4. Road safety audit is a method of formal control carried out by an independent team of experts at different stages of technological readiness of the «product» of the road industry the road. The goal is to identify possible causes of road accidents as early as possible and eliminate them in advance. 
5. The road safety audit is considered as an element of the road safety management system throughout the road life cycle.

6. Road safety audit should be considered as a system of end-to-end quality management (safety for the user) for the technological cycle of the production of a product such as «road».

\section{References}

1. V.F. Babkov. Road conditions and traffic safety. Moscow, Transport Publ., 271 (1993).

2. ODM 218.6.027-2017 Recommendations for conducting a road safety audit in the design, construction and operation of highways, Rosavtodor, Moscow, 102 (2017).

3. V.V. Silyanov, B.B. Anokhin. Ways to improve traffic safety on Russian highways. Nauka $\mathrm{i}$ technica $\mathrm{v}$ doroshnoy otrasli 4, 8-10 (2000).

4. V.V. Silyanov, O.I. Tonkonozhenkov. Audit of road traffic safety in automobile road projects. Nauka i technica v doroshnoy otrasli 1, 2-3 (2007).

5. L. Zhivoglyadova, V. Zhivoglyadov, V. Silyanov. Method for determining integral damage from road accident, IOP Conference Series: Materials Science and Engineering 832, 012060 (2020). DOI: 10.1088/1757-899X/832/1/012060.

6. A.V. Utkin. Trends in the development of BDD in the regions of Russia, Transport: nauka, tekhnika, upravlenie 9, 55-56 (2007).

7. V.V. Chvanov. The main types and causes of road accidents on mountain roads, TrudyMADI, 72-77 (1980).

8. V V Chvanov System analysis of factors contributing to road accidents in the Russian Federation, Collection of Art. Roads and bridges, RosdorNII publ, 43-60 (2006).

9. A.P. Shevyakov. Design of highway elements, MADI Publ., 95 (2010).

10. D. Mohan, G. Tiwari, Road Safety in Less Motorised Countries - Relevance of International Vehicle and Highway Safety Standards, Proceedings International Conference on Vehicle Safety, 155-166, C567/008/2000 (2000). DOI: 10.1136/bmj.324.7346.1142.

11. B. Tatarskih. Organizational and technological problems of material base modernization of russian engineering, 273-278 (2020). DOI: 10.15405/epsbs.2020.03.39.

12. N.Y. Yahyaev, Security vehicles: a textbook. M.: Academy, 432 (2011).

13. R. Zagidullin, T. Gabdullin. Risk of road-traffic accidents in the city of Kazan, IOP Conference Series: Materials Science and Engineering 890, (2020). DOI: 012028. 10.1088/1757-899X/890/1/012028.

14. Ahmed Ishtiaque, Othman Puan, Che Ros. Ismail. A Comparative Review of Road Safety Audit Guidelines of Selected Countries, Jurnal Teknologi 65, (2013). DOI: 10.11113/jt.v65.2148.

15. R.J. Salter, N.B. Hounsell. Highway Traffic Analysis and Design, Third Edition, Hampshire, Great Britain, 392 (1996).

16. F. Wilson, D. Eric. Hildebrand Incorporating the Road Safety Audit Process in a Design Built Project, The Canadian Experience, publ. University of New Brunswick Transportation Group, Canada, $14^{\text {th }}$ IRF Road World Congress, Paris (2001).

17. Institute of Transportation Engineers (ITE), U.S. Department of Transportation, Federal Highway Administration. Road Safety Audits: An Emerging and Effective Tool for Improved Safety. Retrieved from: www.ite.org/technical/IntersectionSafety/RSA.pdf accessed on $3^{\text {rd }}$ July, (2013).

18. FHWA Road Safely Audit Guidelines, Federal Highway Administration N FHWA-SA06-06), Washington, D.C. (2006).

19. M.E. Lipinski, E.M. Wilson. Road Safety Audits: A Synthesis of Highway Practice, National Cooperative Highway Research Program, NCHRP Synthesis 336, (2004). DOI: 10.1016/j.trpro.2017.01.061. 
20. T. Yordphol, P. Taneerananon, L. Srisakda, W. Charoensawan, P. Kunathammarak, Jiwattanakulpaisarn, P. Implementing. Road Safety Audit in Thailand, Journal of the Eastern Asia Society for Transportation Studies 5, (2003). DOI: 10.2471/BLT.09.072249.

21. R. Elvik, B.A. Mysen, T. Vaa, ed. by V.V. Silyanov. Traffic safety handbook: review of traffic safety measures, Translated from Norwegian, (2004).

22. R.L Sakhapov, R.V. Nikolaeva, M.H. Gatiyatullin, M.M. Makhmutov. Asphalt granulate coating for roadsides, MATEC Web of Conferences 245, 02003 (2018), DOI: $10.1051 /$ matecconf/201824503014.

23. The methodology of the audit on road safety during operation of public roads: $M$ 03450778-700:2012. - vved. vpershe 2012-01-01. Kiev, Publ. DerzhdorNDI 63 (2012).

24. Ministry of Transport of the Russian Federation. Methods for assessment and calculation of standards as to social and economic loss resulting from road accidents P-031121990502-00, (2000).

25. R.L. Sakhapov, R.V. Nikolaeva, M.H. Gatiyatullin, M.M. Makhmutov. Modeling of regional transport and logistics systems, Journal of Physics: Conference Series 1141, 012133 (2018). DOI: 10.1088/1742-6596/1141/1/012133.

26. R.L. Sakhapov, M.M. Makhmutov. Innovative technology for monitoring pavements, IOP Conference Series: Materials Science and Engineering 786, 012023 (2020). DOI: 10.1088/1757-899X/786/1/012023.

27. R.L. Sakhapov, M.M. Makhmutov. Influence of removable anti-skid device on the soil density, IOP Conference Series: Materials Science and Engineering 786, 012021 (2020). DOI: 10.1088/1757-899X/786/1/012021.

28. Y. Huvarinen, E. Svatkova, E. Oleshchenko, S. Pushchina. Road Safety Audit, Transportation Research Procedia 20, 236-241 (2017). DOI: 10.1016/j.trpro.2017.01.061. 